\title{
Influence of additional vibration impact on the effectiveness of electrical stimulation procedure
}

\author{
Kiselev M.G., Labun E.I., Liutsko P.S. \\ Belarusian National Technical University, \\ Nezavisimosty Ave., 65, Minsk 220013, Belarus
}

Received 20.02.2017

Accepted for publication 17.05.2017

\begin{abstract}
An experimental instrument complex which includes hardware for performing complex procedures using electrical shock massager frictional action was performed. The aim of the study was to influence the additional vibration effect on the efficiency of the procedure of electrostimulation.

In order to increase the efficiency of the procedure electrostimulation authors proposed to carry it out with using of massager shock-friction action. The changes of muscular indicator on different stimulation treatments was shown after a series of seven treatments .

Results of the processing of the experimental data and its subsequent analysis found that the use of the vibration exposure is accompanied by increase of load parameters in untrained volunteers. The increase in contact area due to decrease in the distance between the nozzle and the axis of rotation of the tumbler body surface, increases the electrical efficiency of the procedure.

On the basis of a generalized analysis of data reflecting the effect of inappropriate electrical stimulation, it was established that, in order to achieve the best results, oscillatory systems providing shock-friction mode of its interaction with the skin surface, in particular a shock-frictional massager, were used.
\end{abstract}

Keywords: electromyostimulation, physiotherapy, active electrode.

DOI: $10.21122 / 2220-9506-2017-8-2-188-194$

Адрес для переписки:

Лабунь Е.И.

Белорусский национальныий технический университет,

пр. Независимости, 65, г. Минск 220013, Беларусь

e-mail: Eugene.labun@gmail.com
Address for correspondence:

Labun E.I.

Belarusian National Technical University,

Nezavisimosty Ave., 65, Minsk 220013, Belarus

e-mail: Eugene.labun@gmail.com

\section{Для цитирования:}

Кабанов Д.М., Лебедок Е.В., Шпак П.В., Жук С.М., Сташкевич С.П.

Influence of additional vibration impact on the effectiveness of

electrical stimulation procedure.

Приборы и методы измерений.

2017. - T. 8, № 2. - C. 188-194.

DOI: $10.21122 / 2220-9506-2017-8-2-188-194$

\section{For citation:}

Kiselev M.G., Labun E.I., Liutsko P.S.

Influence of additional vibration impact on the effectiveness of

electrical stimulation procedure.

Devices and Methods of Measurements.

2017, vol. 8, no. 2, pp. 188-194.

DOI: $10.21122 / 2220-9506-2017-8-2-188-194$ 


\title{
Влияние дополнительного вибрационного воздействия на эффективность проведения процедуры электростимуляции
}

\author{
Киселев М.Г., Лабунь Е.И., Люцко П.С. \\ Белорусский начиональный технический университет, \\ пр. Независимости, 65, г. Минск 220013, Беларусь
}

Поступила 20.02.2017

Принята к печати 17.05.2017

Целью работы являлось изучение влияния дополнительного вибрационного эффекта на эффективность процедуры электростимуляции. Описан экспериментальный приборный комплекс, который включает в себя аппаратный комплекс для выполнения процедуры электростимуляции с использованием массажера ударно-фрикционного действия.

С целью повышения эффективности выполнения процедуры электростимуляции авторами предложено осуществлять еe c использованием массажера ударно-фрикционного действия. Рассмотрены изменения динамометрических характеристик у волонтеров до начала процедур стимуляции и по окончании серии из семи процедур.

В результате обработки полученных экспериментальных данных и их последующего анализа установлено, что применение вибрационного воздействия сопровождается приростом динамометрических параметров у нетренированных волонтеров. Также отмечено, что увеличение частоты вращения насадки при ударно-фрикционном воздействии с 20 до 30 Гц положительно влияет на результативность процедуры.

На основании обобщенного анализа полученных данных, отражающих влияние сообщаемых электроду вынужденных колебаний на протекание процедуры электростимуляции, установлено, что для достижения ее наибольшей эффективности следует использовать колебательные системы, обеспечивающие ударно-фрикционный режим его взаимодействия с поверхностью кожи, в частности массажер ударно-фрикционного действия.

Ключевые слова: электромиостимуляция, физиотерапия, активный электрод.

DOI: $10.21122 / 2220-9506-2017-8-2-188-194$

\section{Адрес для переписки:}

Лабунь Е.И.

Белорусский национальный технический университет,

пр. Независимости, 65, г. Минск 220013, Беларусь

e-mail: Eugene.labun@gmail.com
Address for correspondence:

Labun E.I.

Belarusian National Technical University

Nezavisimosty Ave., 65, Minsk 220013, Belarus

e-mail:Eugene.labun@gmail.com
Для цитирования:

Кабанов Д.М., Лебедок Е.В., Шиак П.В., Жук С.М., Сташкевич С.П.

Influence of additional vibration impact on the effectiveness of electrical stimulation procedure.

Приборы и методы измерений.

2017. - T. 8, № 2. - C. 188-194.

DOI: $10.21122 / 2220-9506-2017-8-2-188-194$
For citation:

Kiselev M.G., Labun E.I., Liutsko P.S.

Influence of additional vibration impact on the effectiveness of electrical stimulation procedure.

Devices and Methods of Measurements.

2017, vol. 8, no. 2, pp. 188-194.

DOI: $10.21122 / 2220-9506-2017-8-2-188-194$ 


\section{Introduction}

Electromyostimulation it is a method of treatment method, which based on electrical stimulation of nerves and muscles, is carried out by through the transfer of current to the adjusted characteristics from myostimulator to the human body through the electrodes. It is widely used for rehabilitation patients after injury with diseases of the central and peripheral nervous system, in professional sport and cosmetology.

Also in common use physiotherapy vibrating massage, which is a kind of biomechanical effects, have a pronounced effect on the muscles causing contraction of muscle fibers and changes in muscle cells. In muscle receive capillaries begin to function reserve that the additional amount of blood, and therefore oxygen. Increases elasticity and muscle performance, growing blood and lymph circulation up, which helps reduce swelling and disappearance of pain.

The research directed to study the effectiveness of vibration as an analgesic during ophthalmic surgery on the eyelid human [1] during injection in cosmetology, dermatology and treatment $[2,3,4]$, pediatrics [5] suggest that that this type of analgesia significantly reduces subjective patients pain. The mechanism of analgesia is due to vibration according to the «pain gate control» theory $[6,7]$. Thus, there is a monitoring mechanism of the level of pain that can be control by means of vibration exposure.

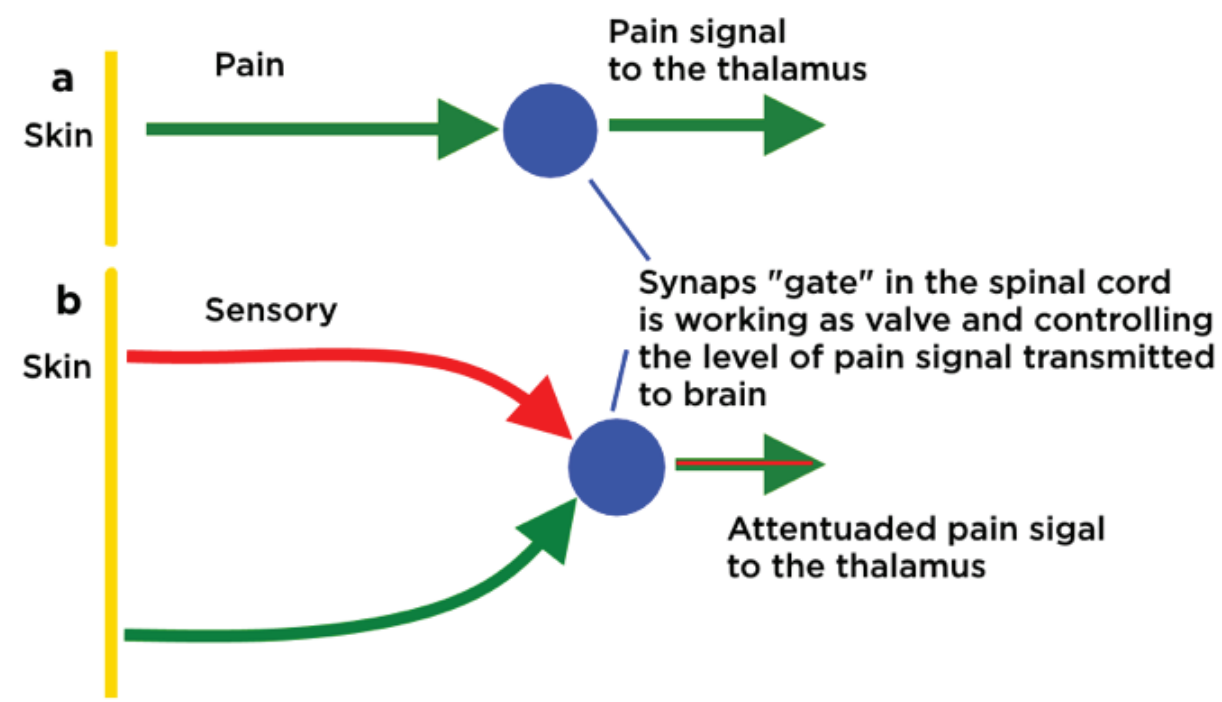

Figure 1 - Simplified diagram that explaining the theory synapse «gate»: a - painful sensations; $\mathrm{b}$ - pain sensations + sensory sensations

An interesting present study of the possibility of combining the use of electrical stimulation and vibration massage in order to increase the efficiency of muscle contraction, reduce pain, if necessary, the use of intense shock impact, improve patients comfort on the procedure.

In the available literature failed to find information about the devices, providing simultaneous vibration and electro-stimulation effects.

Obviously, for the opening mechanism of the combined effects of physical therapy and targeted control them, it is necessary to have data that reflect the impact on the biomechanical effects of separate shock and friction phase rotating blades interact with the human body. Based on the results of the experiments showed the presence of three characteristic steps of interaction with tumbler rotating blade surface of the body, namely: shock, friction and relaxation steps. Also timing of their occurrence were determined based on the nozzle speed and size of blades of interference relative to the body surface. A fundamentally different conditions, these phases contact interacting surfaces and, in particular, their direction of relative movement. So the shock phase can be characterized by periodically relative motion which perpendicular to the interacting surfaces, and the friction unseparated their movement in the tangential direction. For ease of analysis, it suggested to consider vibration exposure in the form of two main types of influence: force and friction. The combination of these two types enables us to provide a special kind of mechanical effect - the frictional shock. This division will evaluate the effect of the direction and frequency of the reported oscillation electrode on the process of vibro influence on the patient's body. Exploration of these issues devoted 
to this work. The aim of the study was to influence the additional vibration effect on the efficiency of the procedure of electrostimulation.

\section{The methodology of experimental research}

Tumbler is connected to a personal computer with software for generating and registering SpectraPro pulse currents and the power supply unit; to strengthen the pulse currents applied amplifier. On the rotating shaft on massager planted head fixedly, wherein the cantilevered leather blade. At their free ends provided steel electrodes $12 \mathrm{X} 18 \mathrm{H} 10 \mathrm{~T}$ («surgical»), made in the form of light metal rivets which power supplied by dint of the collector unit.

The second electrode fixedly secured to the patient's body. When the motor shaft rotated, the blade intermittent impact mechanical on the patient's body surface, providing, on the one hand, they massage the effect, on the other - changing the electrical percolation process mode by periodically interrupting the electrical circuit between the electrodes.

This creates an opportunity to improve the effectiveness of this procedure due to the summation of the effects of electro-stimulation influence and vibrating massage. It also found that there is a nozzle speed range $\mathrm{N}$, in which the combined effect of vibration massage and electrostimulation volunteers tolerated the most comfortable, without pain. In particular, the conditions for the experiments, the optimal value was $150-200 \mathrm{~m} \mathrm{~N}^{-1}$, which, with eight blades, each $80 \mathrm{~mm}$ long, it corresponds to the frequency interrupt circuit equal to $20-30 \mathrm{~Hz}$. This is consistent with the literature [9] for optimum use of frequency bands for electrical and vibratory stimulation. In addition, changes in the departure of the blades with up to $80 \mathrm{~mm}$ larger or smaller values, the alternation of their number, the size, the use of blade material with different elastic properties allow purposefully change the conditions of the process of biomechanical effects.

Using the massager shock-friction action with the function of electrical stimulation can be promising in the treatment and rehabilitation of many diseases such as: radiculopathy compression-ischemic, post-traumatic, neuropathy, plexopathy in patients with cerebrovascular disease traumatic brain injury and post various types of neurosurgical operations with the consequences of the disease in the form of paresis limbs of varying severity skeletal muscle wasting pain and musculo-tonic syndrome. A combination of physiotherapy effects used at the same time enables us to provide an analgesic, muscle relaxant, stimulating effect, duration improve microcirculation in the affected limb, trophic function of the neuromuscular system and cause a normalization of the central and peripheral hemodynamics. Within the individual rehabilitation programs in conjunction with other techniques may enhance the therapeutic effect especially in patients at early stages of rehabilitation.

Furthermore, the combination of these types of effects can be used in cosmetology as an auxiliary means for removing the unwanted effects of liposuction, the appearance of cellulite.

Figure 2 shows the experimental set of applied research. It consists of three main blocks: Block electrostimulation massager shock-friction action and power generation displaced electromagnet vibrations. On the frame 8 arranged adjustable stand 9 , which puts the volunteer arm 1 on which the wiring is fixed first electrode 10 of about $2 \mathrm{~cm}^{2}$ in area hypothenar. By the muscle group flexor in the upper third of the forearm using a magnetic rack 3 electromagnet supplied with the second electrode 2 . The electromagnet oscillation frequency adjusted by generator 5. Generation of electro-stimulation pulse current at the electrodes and their registration provided with a PC 7, and specialized software. Also with a sound card 4 and the booster 6 . In this case it is used a shock-friction massage action 10. Thanks to design electromagnet, it allows messages electrode vibrational displacements in vertical and horizontal planes, which accordingly produces friction and shock interactions with human skin. When using the massager shock-friction action, instead of the electromagnet at the front, to the muscle summed blades with electrodes. This electrode with 1-4 blades were switch off in order to create a full period of muscle relaxation.

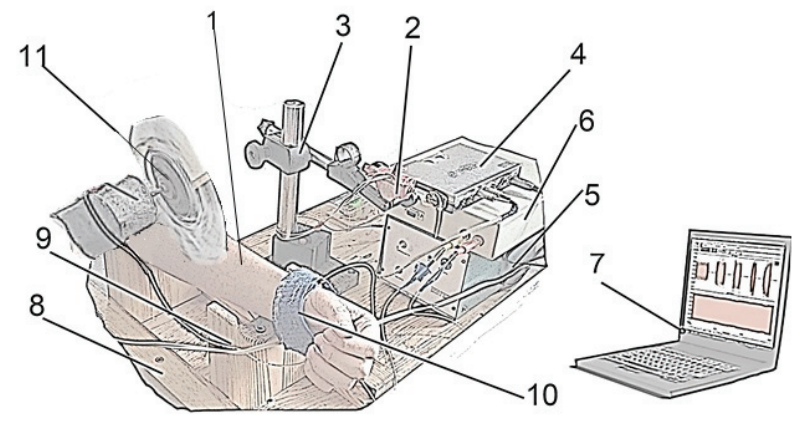

Figure 2 - General view of applied research in experimental complex: 1 - volunteer arm; 2 - electrode; 3 magnetic rack; 4 - sound card; 5 - generator; 6 - booster; 7 - PC; 8 - frame; 9 -adjustable stand; 10 - shock-friction massage action 
For convenience, the following description and analysis of data, reflecting the effect of the direction reported on the process of electrode oscillation amplitude modulation of the electro-stimulation currents, take the following circuit (Figure 3), provisionally designated by the letters $\mathrm{A}, \mathrm{B}, \mathrm{C}$ and $\mathrm{D}$. In implementing the scheme $\mathrm{A}$ electrode 1 reported heave directed perpendicular to the surface 2 of the body, to wit, implemented the conditions of their periodic shock interaction. Scheme B is characterized in that horizontal vibrations $\mathrm{Ag}$ are communicated in parallel electrode surface of the body, and their contacting takes place under frictional engagement unseparated. Scheme $\mathrm{C}$ is fundamentally different from the previous presence of rotational movement blade, on which the electrode, whereby there are successively proceeding stage shock Av and Ar frictional interaction of the human body with the electrode surface. Thus, depending on the value of $\mathrm{H}$ (the distance from the rotational axis to the body surface), the contact area changes. The diagram D mode shows the impact of electric current without any additional mechanical action on the active electrode.
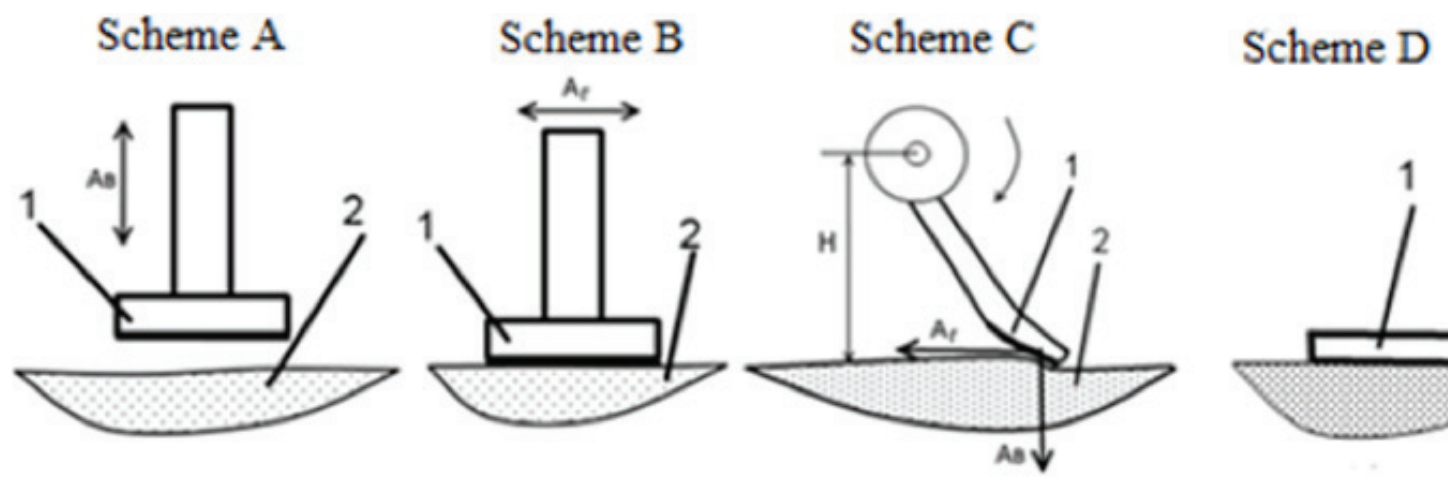

Figure 3 - Schematic diagrams of messages forced oscillations of the active electrode in the process of performing electrical procedures: A - perpendicular to the surface 2 of the body; $\mathrm{B}$ - horizontal vibrations are communicated in parallel electrode surface of the body; $\mathrm{C}$ - presence of rotational movement blade, on which the electrode, whereby there are successively proceeding stage shock Av and Ar frictional interaction of the human body with the electrode surface; $\mathrm{D}$ - the impact of electric current without any additional mechanical action on the active electrode

The methodology of the experiments included the consistent implementation of these actions. Volunteer's hand was placed on adjustable stands in a certain position convenient for the procedure, and the back of the hand facing up, brush relaxed. In the hypothenar was recorded first electrode. A second electrode mounted on the electromagnet (operating according to the schemes $\mathrm{A}$ and $\mathrm{B}$ ) using a magnetic rack and routed to the area of the abdomen muscles so as to provide electrical contact between the electrodes through the skin surface of volunteers in the disengaged position of the electromagnet. Then the electrodes supplied pulse current sine wave with a carrier frequency of $1 \mathrm{kHz}$. According to, the electrodes moistened with $10 \%$ sodium chloride solution to ensure the best mode of electric contact. Voltage was adjust to a level corresponding to the feeling of vibrations from passing current through the body, arising from volunteers (5-30 V depending on subjective parameters volunteers, carrier frequency $1 \mathrm{kHz}$ ), at which the volunteer had a feeling of vibration. Thereafter generator vibration is switched electromagnet electrode active generating oscillations at a frequency of $22-30 \mathrm{~Hz}$ for the frictional effects mode and then to hammer respectively. When using the massager shock-friction action, the procedure was perform under similar conditions. The experiment was conduct for 7 days, daily. Time exposure electro-stimulation current $-300 \mathrm{~s}$. To evaluate the effectiveness of the stimulus exposure, before and after the treatments using electronic wrist dynamometer torque parameters were measured, in particular the brush compression force.

To participate in the experiment, eleven volunteers of both sexes who met the following criteria were select: the lack of any kind was acute, ongoing or chronic illness, lack of excess weight, age from 21 to 30 years.

\section{The results of experiments}

Table summarizes data, showing torque change characteristics in volunteers prior to stimulation treatments and after a series of seven treatments. The level of stimulus voltage corresponds to a threshold, to wit was brought up to the level at which a forced muscle contractions. Marked with an $\left\langle{ }^{*}\right\rangle$ are physically developed by volunteers, are actively involved in sports. 
Change characteristics in volunteers prior to stimulation treatments and after a series of seven treatments

\begin{tabular}{|c|c|c|c|c|}
\hline \multirow[t]{2}{*}{ Volunteer } & \multirow{2}{*}{$\begin{array}{c}\text { Type mechanical effect on the } \\
\text { image } 4\end{array}$} & \multicolumn{2}{|c|}{ The value compression force of the wrist } & \multirow[t]{2}{*}{ Increase torque settings } \\
\hline & & $\begin{array}{l}\text { Prior to the course } \\
\text { of procedures, } \mathrm{N}\end{array}$ & $\begin{array}{l}\text { After the completion of } \\
\text { the procedures, } N\end{array}$ & \\
\hline 1 & In scheme $\mathrm{A}$ & 209 & 245 & $17 \%$ \\
\hline $2^{*}$ & In scheme A & 386 & 405 & $5 \%$ \\
\hline 3 & In scheme B & 278 & 317 & $14 \%$ \\
\hline 4 & In scheme B & 221 & 263 & $19 \%$ \\
\hline 5 & $\begin{array}{c}\text { In scheme C } \\
\mathrm{H}=6 \mathrm{sm}, \\
\mathrm{N}=200 \mathrm{~min}^{-1}\end{array}$ & 245 & 307 & $25 \%$ \\
\hline $6^{*}$ & $\begin{array}{c}\text { In scheme C } \\
\mathrm{H}=8 \mathrm{sm} \\
\mathrm{N}=150 \mathrm{~min}^{-1}\end{array}$ & 291 & 310 & $5 \%$ \\
\hline 7 & $\begin{array}{c}\text { In scheme C } \\
\mathrm{H}=6 \mathrm{sm}, \\
\mathrm{N}=150 \mathrm{~min}^{-1}\end{array}$ & 264 & 315 & $20 \%$ \\
\hline 8 & $\begin{array}{l}\text { In scheme C } \\
\mathrm{H}=8 \mathrm{sm} \\
\mathrm{N}=90 \mathrm{~min}^{-1}\end{array}$ & 268 & 321 & $19 \%$ \\
\hline 9 & In scheme D & 418 & 459 & $10 \%$ \\
\hline 10 & In scheme D & 412 & 460 & $11 \%$ \\
\hline $11^{*}$ & In scheme D & 521 & 545 & $5 \%$ \\
\hline
\end{tabular}

Results of the processing of the experimental data and its subsequent analysis found that the use of the vibration exposure is accompanied by increase of load parameters in untrained volunteers. The increase in contact area due to decrease in the distance between the nozzle and the axis of rotation of the tumbler body surface, increases the electrical efficiency of the procedure. It is also note that the increase in speed at the nozzle shock frictional effects from 20 to $30 \mathrm{~Hz}$ positively affects the performance procedures. Comparison of the effectiveness of different schemes of additional mechanical action during the electrical stimulation treatments suggests that the most effective schemes, involving the use of an additional vibration. In addition, the circuit «B» has the ability to control a wide range of parameters such as the nozzle speed, number of blades, the number of electrodes on the blades; that, except for changes in the mode of mechanical action allows purposefully change the parameters of mechanical electro-stimulation modulation current. Guided Scheme B, from the point of view of mechanics, only frictional oscillation frequency can be controlled, thus it has a more limited capacity massage. Figure 4 shows the pulses the forms of which were obtain by the shock (Figure $4 b$ ). Friction (Figure $4 c$ ) types of effects using the massager shock-friction action (Figure $4 d$ ) to the nozzle speed $\mathrm{N}=150 \mathrm{~min}$ the distance from the body surface to the axis of rotation of the nozzle was $65 \mathrm{~mm}$. Figure $4 a$ shows the shape of the original signal pulses.

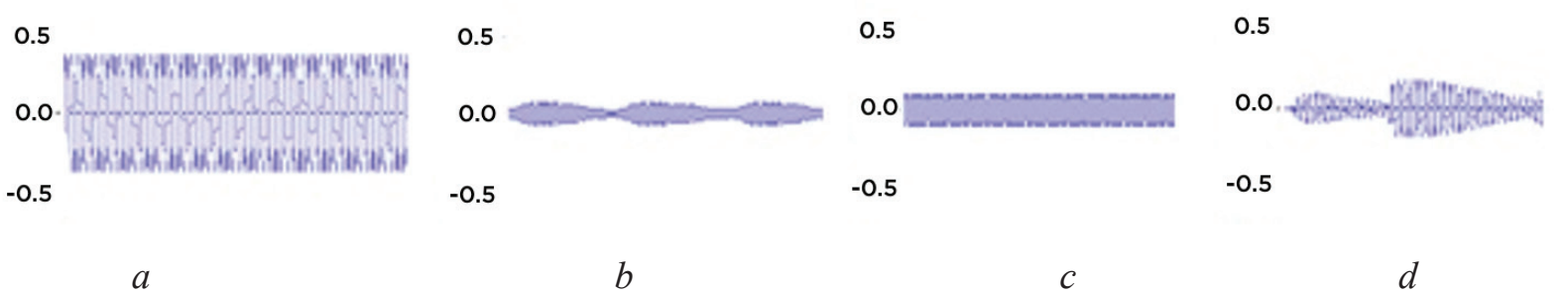

Figure 4 - The pulse form of electro-stimulation current at different areas of the active electrode vibrations: $a$ - original signal; $b$-impact force, $c$ - frictional action; $d$ - shock-friction action

The pulses form of electro-stimulation cur- $150 \mathrm{~min}^{-1}$ with four series-electric active ski blades rent with shock-friction impact at the nozzle speed is shown in Figure 5. 


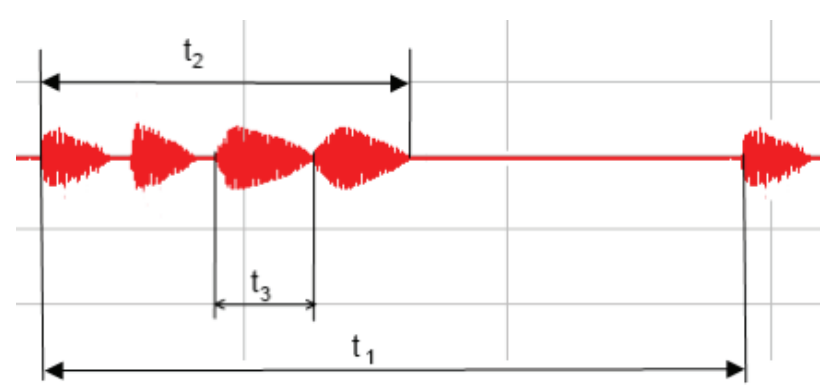

Figure 5 - The pulse form electro-stimulation current when exposed to shock-friction: $t_{1}=0,4 \mathrm{~s}(2.5 \mathrm{~Hz})-$ time period corresponding to one nozzle turnover; $t_{2}=0,2 \mathrm{~s}$ $(5 \mathrm{~Hz})$ - the duration of feeding four consecutive series of pulses; $t_{3}=0,05 \mathrm{~s}(20 \mathrm{~Hz})-$ the duration of a series of pulses

Existence of relaxation phase of muscular tension with shock-friction impact is evidently. At the period $t_{1}-t_{2}$ there is no muscular tension, while lymph drainage is active.

\section{Conclusion}

The method was developed and created experimental facility that allows for electrical communication with the electrode process of forced oscillations of different frequencies and amplitudes in three directions relative to the surface of the skin, providing a variety of conditions of contact interaction. In particular, the terms of the vibro-impact interaction, when the vibrational displacement of the electrode are directed perpendicular to the skin surface, the friction - when oscillating displacement act parallel to, and shock-friction, in which it holds periodic oblique collision with the electrode surface.

Determined that of the results of previous research on the combined use of vibration and electrical stimulation, the possibility of strengthening the impact of the stimulus both due to periodic mechanical stimulation of the muscles, and by influencing her pulse current frequency 20-30 Gts.

Determined that of experimental data obtained on 11 volunteers established the following. Compared with the performance of electrical stimulation procedures without vibration of the active electrode, the electrode connection of forced oscillations in all cases increases the effectiveness of its implementation, as evidenced by higher than in the first case, the percentage increase in torque indicator volunteers.
The highest average value of this index observed in shock-friction impact, somewhat smaller on impact, even less - when they exposed to friction, and its minimum value correspond to the conditions of the procedure without the use of the vibration of the active electrode.

Determined that of the data, reflecting the impact of the reported electrode forced oscillations on the flow of electrical stimulation procedure is established that in order to achieve its maximum efficiency, use oscillatory system providing shock-friction mode of its inter-action with the surface of the skin, in particular shock Massager shock-friction action.

\section{References}

1. Fayers T., Morris D.S., Dolman P.J. Vibration-assisted anesthesia in eyelid surgery. Ophthalmology, 2010, pp. 19-36. doi: 10.1016/j.ophtha.2009.11.025

2. Stoecker W.V., Malters J.M., Xu J., Pikka J. Dermatol Online J. Tripod vibration anesthesia, 2008, pp. 54-75.

3. Nanitsos E., Vartuli R., Forte A., Dennison P.J., Peck C.C. Aust Dent J. The effect of vibration on pain during local anaesthesia injections, 2009, pp. 112-120. doi: $10.1111 / \mathrm{j} .1834-7819.2009 .01100 . \mathrm{x}$

4. Aesthet Surg J. Sharma P., Czyz C.N., Wulc A.E. Investigating the efficacy of vibration anesthesia to reduce pain from cosmetic botulinum toxin injections, 2011, pp. 71-84. doi: 10.1177/1090820X11422809

5. Baba L.R., McGrath J.M., Liu J., Nursing Faculty J. Perinat. The efficacy of mechanical vibration analgesia for relief of heel stick pain in neonates: a novel approach, 2010, pp. 81-92. doi: 10.1097/JPN.0b013e3181 ea7350

6. Kevin C., Smith M.D., Stephen L., Comite M.D., Suprina Balasubramanian, Alan Carver MDa and Judy F. Liu. Vibration anesthesia: A noninvasive method of reducing discomfort prior to dermatologic. Dermatology Online Journal, 2015, no. 10 (2), pp. 32-44.

7. Lundeberg T., Ekblom A., Hansson P. Relief of sinus pain by vibratory stimulation. 1985, pp. 12-18.

8. Osipov A.N., Kiselev M.G., Labun E.I. [Experimental evaluation of analgesic effect at combined effect of electrostimulation and shock-frictional massage ]. Reports of BSUIR, 2012, no. 5, pp. 5-8 (in Russian).

9. Kiselev M.G., Labun E.I. [Experimental technique for assessing the analgesic effect of complex effects of electrostimulation and shock-friction massage and recording of mechanical modulation of impulse currents]. Devices and measurement methods, 2012, no. 2(5), pp. 95-99 (in Russian). 